\title{
Ligamen periodontal sebagai pendukung gaya kunyah Periodontal ligament acts to support mastication force
}

\author{
${ }^{1}$ Rachman Ardan, ${ }^{2}$ Ine Suhartina, ${ }^{3}$ Rasmi Rikmasari, ${ }^{3}$ Gantini Subrata, ${ }^{3}$ Erna Kurnikasari, \\ ${ }^{3}$ Deddy Firman \\ ${ }^{1}$ Fakultas Kedokteran, Universitas Jenderal Achmad Yani, Cimahi \\ ${ }^{2}$ Bagian Oral Biologi, Fakultas Kedokteran Gigi Universitas Padjadjaran, Bandung \\ ${ }^{3}$ Bagian Prostodontik, Fakultas Kedokteran Gigi Universitas Padjadjaran, Bandung \\ Indonesia
}

\begin{abstract}
Support for removable partial denture (RPD) can be obtained from bone supported mucosa and or from periodontal ligament of tooth. Support can also be obtained from implant. Tooth support (periodontal ligament) is better than mucosal support because histologically, anatomically, and also physiologically, in addition, periodontal ligament acts to resist mastication force.
\end{abstract}

Key words: support, removable partial denture, periodontal ligament, mucosal

\section{ABSTRAK}

Dukungan untuk gigitiruan sebagian lepasan (GTSL) dapat diperoleh dari mukosa yang didukung tulang di bawahnya dan atau dari ligamen periodontal gigi. Selain itu dukungan juga dapat diperoleh dari implan. Dukungan melalui gigi (ligamen periodontal) lebih baik daripada dukungan dari mukosa, karena secara histologis, anatomis, maupun fisiologis fungsinya ditujukan untuk menahan gaya kunyah.

Kata kunci: dukungan, gigitiruan sebagian lepasan sementara, ligamen periodontal, mukosa

Koresponden: Rahman Ardan, e-mail: rach7544@yahoo.com

\section{PENDAHULUAN}

Fungsi gigitiruan umumnya, baik lepasan maupun cekat, adalah untuk pengunyahan, pengucapan, dan estetika. Untuk pengunyahan, gigitiruan perlu stabil saat mengunyah. Stabilitas gigitiruan antara lain diperoleh karena ada jaringan keras di bawahnya, yaitu gigi dengan ligamen periodontal melalui melalui sandaran oklusal dan mukosa dengan tulang di bawahnya. Syarat lainnya, yaitu batas kemampuan dan luas jaringan setempat, besar dan arah gaya kunyah serta dukungan yang merata. Stabilitas gigitiruan bukan diperoleh dari retensi yang sangat kuat, karena merusak bagian yang dipakai untuk retensi. Secara alami ligamen periodontal sampai batas tertentu mampu menjaga kesehatannya, karena itu dukungannya jauh lebih baik dibandingkan dengan dukungan mukosa dengan tulang di bawahnya. ${ }^{1}$

Melalui artikel ini akan dibahas mengenai keunggulan ligamentum periodontal sebagai pendukung gaya kunyah terutama jika dibandingkan dengan dukungan mukosa.

\section{TINJAUAN PUSTAKA}

\section{Ligamen periodontal}

Ligamen periodontal merupakan bagian dari periodonsium yang terdiri dari gingiva, ligamen periodontal, sementum, serta tulang alveolar. Ligamen periodontal adalah jaringan ikat yang meliputi akar gigi dan menghubungkan sementum pada akar gigi tersebut dengan tulang alveolar. ${ }^{2}$

Bagian terpenting dari ligamen periodontal yang berfungsi untuk menahan gaya kunyah adalah serat-serat (fiber). Bagian ini merupakan serat kolagen, tersusun berkelompok, berjalan bergelombang (Gambar 1). Bagian ujung serat yang tertanam pada lapisan semen dan tulang disebut serat Sharpey. ${ }^{2}$ Serat-serat periodontal terdiri dari beberapa grup, yaitu transeptal, alveolar crest, horisontal/oblique (miring), dan serat apikal.

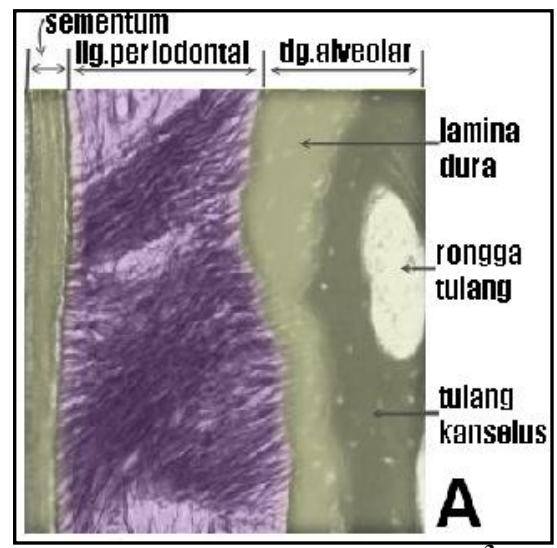

Gambar 1. Ligamen periodontal 
Grup serat-serat periodontal yang paling besar adalah yang berjalan miring. Serat-serat ini berjalan miring dari bagian lamina dura ke arah semen pada gigi. Fungsi utama serat-serat ini adalah untuk menahan gaya kunyah yang mengenai gigi, dan mengubahnya menjadi tarikan/tegangan sehingga terjadi peregangan pada serat periodontal yang berjalan miring. Serat-serat ligamen periodontal berjalan bergelombang, karena itu peregangan terjadi dengan baik sehingga akan dapat mengurangi kemungkinan terjadinya trauma akibat gaya kunyah.

Selain serat-serat pada ligamen periodontal, juga antara lain ada sel-sel fibroblas, sel endotel, sementoblas, dan osteoklas. Aliran darah berasal dari pembuluh darah di apikal gigi yang berasal dari pembuluh darah yang masuk dari tulang alveolar dan dari arah gingiva. Ligamen periodontal juga mengandung serabut saraf sensori yang dapat memberi informasi taktil, tekanan, dan rasa sakit melalui batang saraf trigeminus.

Dari uraian tersebut, terlihat bahwa ligamen periodontal mempunyai fungsi yang bersifat fisik, formatif, nutrisi, dan sensori. Fungsi fisik ligamen periodontal adalah menyalurkan gaya kunyah ke tulang, mengikat gigi ke tulang, memelihara hubungan antara gingiva dengan gigi, sebagai penyerap syok pada fungsi pengunyahan, dan tempat berlindung bagi pembuluh darah dan saraf.

\section{Dukungan gigi (ligamen periodontal)}

Ada tiga teori mekanisme dukungan gigi sebagai penyerap syok, yaitu teori peregangan, teori sistem viskoelastik, dan teori tiksotropik.

Teori peregangan dijelaskan sebagai berikut, pada waktu gaya kunyah mengenai mahkota gigi, serat-serat utama yang sebelumnya berjalan bergelombang akan meregang menjadi lebih panjang dan lebih lurus. Selanjutnya gaya disalurkan kepada tulang alveolar sehingga tulang mengalami deformasi elastik. Apabila sudah mencapai batas kemampuan tulang alveolar, maka gaya akan diteruskan kepada tulang basal. ${ }^{2}$

Teori sistem viskoelastik menjelaskan viskoelastisitas adalah sifat bahan yang bersifat kental dan elastis ketika mengalami perubahan bentuk. Bahan kental contohnya minyak pelumas, dapat melindungi pergeseran dan peregangan sejalan dengan waktu pada saat dikenai tekanan. Bahan elastik akan segera meregang apabila ditarik dan segera kembali ke bentuk semula saat tekanan dihilangkan. Bahan viskoelastik mempunyai unsur-unsur dari kedua sifat ini dan ketegangan yang terjadi bergantung pada waktu. ${ }^{4}$
Eksperimen yang meneliti perilaku terjadinya quasi-linear viscoelastic (QLV) pada gigi premolar kadaver menunjukkan adanya perbedaan tingkat peregangan sepanjang akar gigi. ${ }^{5}$ Sifat viskoelastik suatu bahan terjadi pada saat dikenai gaya kunyah sesaat, dan perilakunya juga ditentukan oleh memori sebelumnya. ${ }^{4}$ Penelitian in vitro pada spesimen ligamen periodontal berasal dari babi dewasa menunjukkan terjadinya kurva tekanan-peregangan siklik. $^{6}$ Model viskoelastik ligamen periodontal mampu menahan peregangan dalam berbagai arah dan efeknya tergantung pada waktu dan sifat alami jaringan, terutama serat-serat kolagen serta mikrostruktur yang akan memodifikasi saat terjadinya beban.

Sedangkan teori tiksotropik, teori ini berdasarkan pada adanya respon fisiologis ligamen periodontal yang secara biologis berubah viskositasnya. Biologi ligamen periodontal belum difahami seluruhnya, dan terjadinya suatu respon dinamis jaringan terhadap beban yang dapat dijelaskan dengan adanya perubahan viskositas pada matrik jaringan kolagen. ${ }^{7}$ Penelitian yang lain menunjukkan satu pola pemulihan viskoelastis serupa terdiri dari satu respon elastis jangka pendek (setelah satu 1 menit, sudah terjadi $82 \%$ pemulihan) dan 30 menit kemudian masih terjadi perubahan viskositas setelah sebanyak $6 \%{ }^{8}$

\section{PEMBAHASAN}

Ketiga macam teori mekanisme dukungan gigi terhadap beban menunjukkan bahwa masih diperlukan penelitian lebih lanjut. Ketiga teori tersebut merangkum fisiologi kekentalan cairan periodontal, serat-serat kolagen, elastisitas, serta struktur histologis ligamen periodontal. Semuanya menjelaskan proses yang sama dengan menggunakan istilah-istilah yang sedikit berbeda.

Selain peranan dukungan gigi sebagai penyerap syok, ada empat hal lain yang menyebabkan dukungan dari gigi adalah lebih baik, yaitu cairan ekstrasel ligamen periodontal dan pori-pori pada lamina dura, perubahan tekanan menjadi tarikan, adanya reseptor saraf, ${ }^{9}$ dan jaringan periodontal gigi yang hilang lebih luas daripada mukosa bekas gigi tersebut. ${ }^{1}$

Pada saat gaya kunyah kunyah mengenai gigi, cairan cairan ekstraseluler ligamen periodontal mengalir perlahan-lahan ke arah rongga-rongga tulang melalui pori-pori kecil pada lapisan lamina dura tulang alveolar ligamen periodontal (gambar 2). Pengeluaran cairan terjadi perlahan-lahan sehingga dukungan yang terjadi bersifat sebagai penyerap syok. 
Selanjutnya, dengan terjadinya tarikan pada ligamen periodontal maka bahan-bahan nutrisi, sistem pertahanan pemeliharaan akan masuk sehingga akan mempertahankan dan atau memperbaiki kesehatan jaringan setempat. Sebaliknya apabila terjadi tekanan akan menyebabkan bahan-bahan nutrisi, sistem pertahanan dan pemeliharaan akan keluar atau terhambat masuk jaringan, sehingga dapat terjadi kerusakan jaringan setempat yang dapat berupa jaringan nekrotik atau resorpsi jaringan.

Gigi dilengkapi dengan mekanoreseptor periodontal untuk menerima sinyal informasi terhadap gaya kunyah. Reseptor saraf (gambar 3) berfungsi sebagai alarm bahaya bila gaya kunyah akan menyebabkan trauma dengan cara terjadinya gerak reflek. ${ }^{9}$ Penelitian Oki et al pada 18 subjek dengan usia rata-rata 27,2 $\pm 5,7$ tahun untuk menentukan ambang persepsi gaya yang diaplikasikan terhadap gigi normal menunjukkan fluktuasi persepsi terhadap gaya kunyah selama satu hari maupun dari hari ke hari tidak ada perbedaan yang nyata, akan tetapi beban mekanis sesaat menyebabkan sensitivitas ligamen periodontal akan makin berkurang. ${ }^{10}$ Perubahan arah gaya kunyah yang menjadi kebiasaan dapat menyebabkan perubahan morfologi mekanoreseptor. ${ }^{11}$ Mikroneurografik sebuah serat saraf menunjukkan bahwa ligamen periodontal beradaptasi perlahan-lahan terhadap gaya kunyah. Mekanoreseptor periodontal akan mengkode gaya kunyah yang terjadi saat pengunyahan dan digunakan untuk mengontrol gerak pengunyahan rahang. ${ }^{12}$ Penelitian pada gigi insisivus sentralis rahang atas yang diberi rangsang mekanik terkontrol pada 19 orang subjek dan reflek pada otot maseter di ipsilateral diamati secara elektromiogram. ${ }^{13}$ Dari hasil penelitian tersebut dapat disimpulkan bahwa mekanoreseptor pada ligamen periodontal berperan untuk mengendalikan otot-otot penutup rahang, khususnya pada respon refleks laten yang singkat.

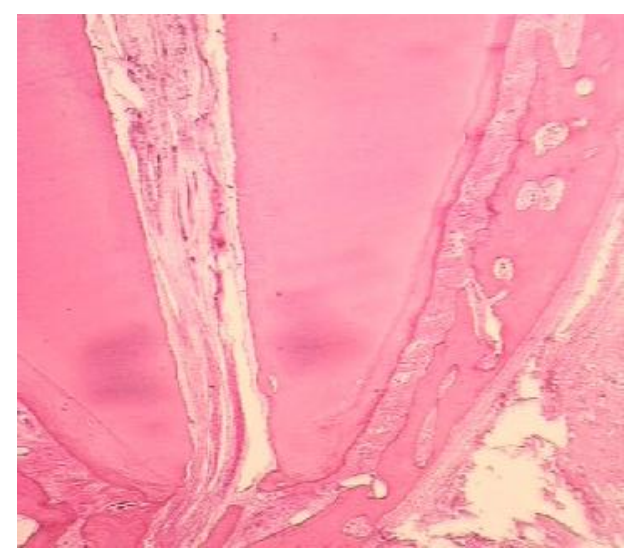

Gambar 2. Vaskularisasi melalui pori-pori kecil. $^{3}$

Pada kasus GTSL dengan kehilangan gigi Kennedy kelas III, apabila hanya memanfaatkan dukungan mukosa mastikatori seluas daerah bekas gigi yang sudah dicabut tidak akan cukup karena luas mukosa di tempat tersebut lebih kecil daripada luas ligamen periodontal giginya yang sudah tidak ada (gambar 4 dan 5). Hasil analisis perbandingan luas ligamen periodontal gigi yang sudah dicabut dengan luas mukosa di tempat tersebut menunjukkan tiga sampai lima kali lebih luas (tabel 1). ${ }^{1}$

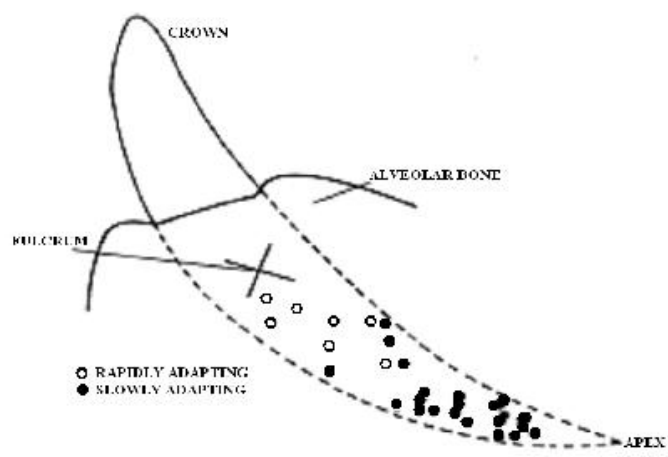

Gambar 3. Distribusi 30 mekanoreseptor yang terletak pada satu sisi ligamen periodontal gigi kaninus kucing ${ }^{9}$

Tabel 1. Luas mukosa dan luas ligamen periodontal pada setiap gigi $\left(\mathrm{mm}^{2}\right){ }^{1}$

\begin{tabular}{|c|c|c|c|c|c|c|}
\hline \multirow{3}{*}{ Gigi } & \multicolumn{2}{|c|}{ Mukosa } & \multicolumn{4}{|c|}{ Ligamen Periodontal } \\
\hline & \multirow{2}{*}{ Maksila } & \multirow{2}{*}{ Mandibula } & \multicolumn{2}{|c|}{ Maksila } & \multicolumn{2}{|c|}{ Mandibula } \\
\hline & & & & Lebih luas & & Lebih luas \\
\hline Insisivus sentralis & 62,30 & 31,20 & 204 & 3,27 kali & 154 & 4,94 kali \\
\hline Insisivus lateralis & 39,68 & 38,35 & 179 & 4,50 kali & 168 & 4,38 kali \\
\hline Kaninus & 60,80 & 53,13 & 273 & 4,50 kali & 268 & 5,00 kali \\
\hline Premolar pertama & 64,80 & 49,64 & 234 & 3,61 kali & 180 & 3,63 kali \\
\hline Premolar kedua & 56,10 & 57,40 & 220 & 3,92 kali & 207 & 3,61 kali \\
\hline Molar pertama & 125,08 & 113,22 & 433 & 3,54 kali & 431 & 3,81 kali \\
\hline Molar kedua & 109,25 & 107,06 & 431 & 3,95 kali & 426 & 3,98 kali \\
\hline
\end{tabular}




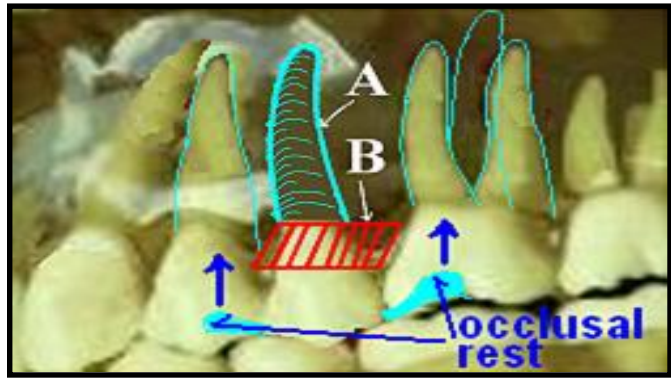

Gambar 4. A=Ligamen periodontal (warna hijau) jauh lebih luas daripada $\mathrm{B}=$ mukosa pendukung gigi penggantinya (warna merah). ${ }^{1}$

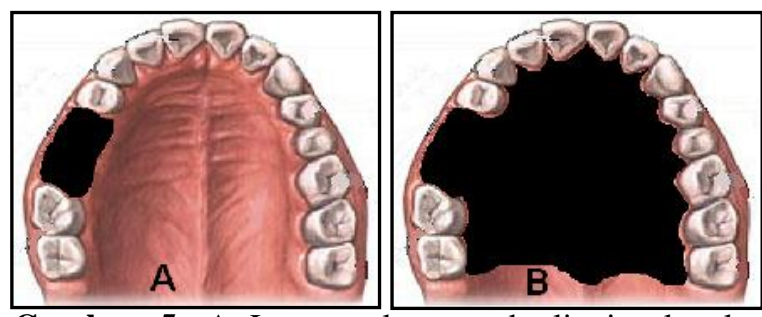

Gambar 5. A=Luas mukosa pada lingir alveolar sesuai dengan luas tempat gigi yang sudah dicabut (diberi warna hitam). $\mathrm{B}=$ Perluasan landasan

Selain luas mukosa pendukung lebih kecil dibanding ligamen periodontal, mekanisme dukungan seperti yang terjadi pada ligamen periodontal tidak terjadi. Untuk meningkatkan dukungan mukosa dapat dilakukan dengan cara memperluas landasan. Akan tetapi cara perluasan landasan ini mempunyai banyak kelemahan, antara lain kenyamanan pemakaian gigitiruan terganggu, perluasan landasan bukan berarti pemerataan gaya kunyah ke seluruh landasan, karena tekanan paling besar tetap berada di lokasi tempat kerja beban, dan gaya kunyah terhadap mukosa melalui landasan merupakan tekanan bukan tarikan

Ada beberapa kondisi yang akan mempengaruhi kemampuan gigi untuk menahan gaya kunyah, antara lain bentuk morfologi akar, luas permukaan akar yang didukung tulang, perbandingan panjang mahkota terhadap akar, serta mobilitas gigi. ${ }^{15}$

\section{SIMPULAN}

Dari pembahasan mengenai ligamen periodontal sebagai pendukung gaya kunyah, dapat simpulkan bahwa struktur histologis maupun fisiologis ligamen periodontal sangat baik untuk menerima gaya kunyah, dukungan utama untuk GTSL harus memanfaatkan dukungan dari gigi melalui sandaran oklusal, dan dukungan mukosa dapat digunakan terutama apabila diperkirakan dukungan dari gigi tidak cukup.

\section{SARAN}

Pada pembuatan GTSL harus diutamakan dukungan dari gigi sandaran dengan pembuatan sandaran oklusal di kedua ujung sadel, serta dalam pemilihan gigi sandaran untuk penempatan sandaran oklusal perlu pertimbangan faktor-faktor lain terutama keadaan gigi sandaran itu sendiri, antara lain kesehatan jaringan periodonsium, anatomi gigi, dukungan tulang alveolar pada akar gigi, dan lain-lain.

\section{DAFTAR PUSTAKA}

1. Ardan R. Luas permukaan akar gigi dan luas permukaan mukosa setempat sebagai jaringan pendukung gigi tiruan. Proceeding of the Dentistry 7, PDGI Bandung, 4 Juni, 2010.

2. Carranza FA. Glickman's clinical periodontology. $6^{\text {th }}$ Ed. Tokyo: W.B. Saunders Co./ Igaku Saunders; 1984. p. 29-81.

3. Rosentiel SF, Land MF, Fujimoto J. Contemporary fixed prosthodontics. $3^{\text {rd }}$ Ed. St.Louis: Mosby Inc.; 2001.

4. Christensen RM. Theory of viscoelasticity. $2^{\text {nd }}$ Ed. New York: Dover Publ.Inc, Mineola; 2003. p. 1-2.

5. Toms SR. Quasi-linier viscoelastic behavior of the human periodontal ligament. J Biomech 2002; 35 (10): 1411-5

6. Natali AN, Pavan PG, Carniel EL, Dorow C. Viscoelastic response of the periodontal ligament: an experimental numerical analisis. Connect Tissue Res 2004; 45: 222-30.

7. Kardos TB, Simpson LO. A new periodontal membrane biology based upon thicotropic concepts. Am J Orthod 1980; 77(5): 508-15.

8. Brosh T. Deformation/recovery cycle of the periodontak ligament in human teeth with single or dual contact points. Arch Oral Biol 2002; 47(1): 8592.

9. Cash RM, Linden RWA. The Distribution of mechanoreceptors in the periodontal ligament of the mandibular canine tooth of the cat. J Physiol 1982; 330: 439-47.

10. Oki K, Hamanaka M, Arima T, Takahashi S, Hasegawa K, Minagi S. A new method for evaluating the threshold of periodontal ligament mechanoreceptor by slow speed mechanical stimulation. J Periodontol Res 2003; 38 (5): $482-7$.

11. Piyapattamin T, Takano Y, Eto K, Soma K. Morphological change in periodontal mechanorceptor of mouse maxillary incisors after the experimental induction of anterior crossbite: a light and electron microscopic observation using immunohistochemistry for PGP 9.5. Eur J Orthod 1999; 21: 15-29.

12. Trulsson M. Sensory motor function of human periodontal mechanoreceptors. J Oral Rehabil 2006; 33(4): 262-73. 
13. Louca C, Cadden SW, Linden RWA. The roles of periodontal ligament mechanoreceptors in the reflex control of human jaw-closing muscles. Brain Res 1996; 731(1-2): 63-71.

14. Millar BJ, Halata Z, Linden RWA. The structure of physiologically located periodontal ligament mechanoreceptors of the cat canine tooth. J Anat 1989; 167: 117-27.

15. Boucher LJ, Renner RP. Treatment of partially edentulous patients. St Louis: The CV Mosby Co., 1982. 